\title{
POJĘCIE HEREZJI JAKO NARZĘDZIE SPRAWOWANIA WŁADZY W DYSKURSIE MEDIALNYM
}

Monika Strupiechowska

Uniwersytet Warszawski

\section{/// Wprowadzenie}

Z perspektywy nauk społecznych i zjawiska upowszechniania się dostępu do tworzenia dyskursu medialnego pojęcie „herezji” w coraz większym stopniu odchodzi od znaczenia uzgodnionego w debacie naukowej i teologicznej. Potencjał badawczy współczesnych fenomenów, ujmowanych od strony niezakorzenionej w ścisłej interpretacji nauk Kościoła rzymskokatolickiego (tym samym niedefiniowanych przez „dyspozytariusza Prawdy”), wykazują zwłaszcza te zjawiska, która mają miejsce w dyskursie publicznym w efekcie „nowej ewangelizacji” i „odnowy Kościoła”, z drugiej strony laicyzacji i kryzysu wiary. Współczesną formą anatemy, na którą wskazuje analiza dyskursu medialnego, związanego z powszechnym użyciem słowa „herezja”, wydaje się wykluczenie z debaty czy unieważnienie stanowiska jako niezgodnego z przyjętą hierarchią wartości. Częstość posługiwania się badanym określeniem widoczna jest przede wszystkim w środowiskach konserwatywnych, przyjmujących tradycyjny model wartości.

W artykule zanalizowano dwa zjawiska, określane w dyskursie prawicowym mianem herezji: herezję homoseksualną (tzw. homoherezję) i herezję nacjonalistyczną. Przykłady te są użyciem pojęcia w znaczeniu nieuzgodnionym w Kodeksie Prawa Kanonicznego (KPK). W obu przypadkach odnosi się ono nie tyle do uporczywego zaprzeczania naukom 
Kościoła, ile do oceny działań niedookreślonej zbiorowości manifestujacej własne interpretacje Pisma i nauczania. Tym samym w analizowanych fenomenach wskazanie heretyków nie prowadzi i nie może prowadzić do podjęcia działań określonych w KPK (cenzury, ekspiacji czy pokuty). Zmiany w nauczaniu Kościoła na przestrzeni wieków (widoczne choćby w dokumentach papieskich) oraz wielość interpretacji Pisma (ograniczana przyjęciem jej części do nauczania Magisterium Kościoła) pozwalają badanym grupom - osobom identyfikującym się z poglądami nacjonalistycznymi, klerowi, środowiskom homoseksualnym - tworzyć reinterpretacje nauczania, powołujące się na zasady wiary (w kontekście analizowanego $\mathrm{w}$ artykule zagadnienia najczęściej pojawia się w dyskursie miłosierdzie okazywane każdemu bliźniemu), oraz pozbawione głębszej analizy reinterpretacje fragmentów Pisma Świętego. Droga „nowej ewangelizacji” wytyczona przez papieża Franciszka oraz związany z tym lewicowy skręt nauk doprowadziły do powstania napięć na łonie Kościoła rzymskokatolickiego. Główną ich osią wydaje się zbyt liberalne - dla tradycjonalistów upatrujacych w katolickim modernizmie schyłku wiary - podejście do tradycyjnych nauk Kościoła: zarówno w przypisywaniu Kościołowi odpowiedzialności za zmiany klimatyczne, jak i stosunku do osób homoseksualnych i kwestii pełnienia przez nie posługi kapłańskiej. Pojęcie „herezji” w analizowanych przypadkach pozwala osłabiać postulaty „kacerzy” jako niezgodne z nauczaniem, będące skutkiem ulegania modernizmowi. Stanowi manifestację kontrzmiany do postępującej liberalizacji zasad, co za Benjaminem Barberem nazwać można przeciwstawieniem „McŚwiatowi” - rzeczywistości globalnej, dającej możliwość selekcji przestrzeganych zasad - swego rodzaju fundamentalizmu, „dżihadu”, czyli powrotu do surowej tradycji religijnej (Barber 2004). Tak ujęty proces pozwala wnioskować, że posługiwanie się pojęciem herezji jest jednym z narzędzi walki z procesami modernizacyjnymi, a zarazem przejawem tego, co Peter Berger nazywa „desekularyzacja”" (Berger 1999). Daje możliwość wykluczania fenomenu z debaty, legitymizując argumenty wykluczającego poprzez odwołanie się do obrony kluczowych (tradycyjnych) wartości. Definicja herezji, od której oczekiwać można niezmienności w nauczaniu Kościoła, w debacie medialnej podlega ciagłym przemianom, których czynniki i uwarunkowania są przedmiotem artykułu. 


\section{/// Metodologia}

W artykule zastosowano metodę krytycznej analizy dyskursu medialnego. Analizie poddano artykuły prasowe, dobrane ze względu na specyfikę tematu, głównie w mediach określanych jako prawicowe („Polonia Christiana”, „wPolityce”) oraz katolickie („Deon”, „Opoka”; prawicowe: „Radio Maryja”, „Gość Niedzielny”, „Niedziela”, i lewicowe: „Tygodnik Powszechny"1). Przeanalizowano także dokumenty zawierające interpretacje nauk i wykładnię Kościoła w badanych kwestiach. Artykuł koncentruje się na obecnych w dyskursie publicznym sposobach budowania definicji ,herezji" i jej zwalczania (oraz konsekwencji tych procesów), zarówno w ramach Kościoła, jak i przez członków innych wspólnot i grup społecznych. Zauważyć można ponadto, że w dyskursie publicznym pojęcie herezji staje się tożsame z każdym odstępstwem od dominującej interpretacji rzeczywistości (m.in. kwestia stosunku do przyjmowania uchodźców czy zmian klimatycznych) niejako narzuconej przez zwolenników desekularyzacji. Powstaja tym samym sprzeczne interpretacje, znajdujące uzasadnienie w Piśmie.

Konstytuujące się przez odwołanie do tradycji i historycznego porządku elity symboliczne poprzez działania dyskursywne realizuja funkcje związane ze sprawowaniem władzy, ustanawianiem prawa i regulacja zagadnień politycznych, a także hierarchią spraw ważnych i nieważnych (van Dijk 1993: 46-47). Ich działania legitymizowane są poprzez włączanie do dyskursu wypowiedzi zwykłych obywateli, zaniepokojonych charakterystycznymi dla późnej nowoczesności przemianami obyczajowości. Dyskursywna władza elit symbolicznych realizuje się poprzez duszpasterstwo i zwiększanie dobrobytu (bezpieczeństwa) członków wspólnoty, co odbywa się poprzez szerokie regulacje zachowań i narzucanie własnej interpretacji rzeczywistości (Hindes 1999: 124-125). Ochrona pewnej wersji zgodności z przywróconą tradycyjną interpretacją jawi się $\mathrm{w}$ analizie jako warunek przetrwania instytucji, w szczególności w obliczu obecnego w Europie Zachodniej kryzysu wiary i zmiany roli Kościoła w życiu społecznym i politycznym.

W artykule zostały rozpoznane grupy interesu zaangażowane w budowanie definicji „herezji”. Zbadanie zjawiska wydaje się zasadne także w obliczu „moralnej schizmy”, jaką wieszczy się Kościołowi rzymskokatolickiemu w związku z pontyfikatem i działalnością papieża Franciszka.

1 Zastosowana dystynkcja w odniesieniu do mediów opiera się na ich sile zaangażowania w tworzenie dyskursu politycznego. Analizowane w artykule materiały pochodzą z mediów katolickich, jednak podstawową zauważalną różnicą jest tworzenie politycznej siatki interpretacyjnej przez ich autorów. 


\section{/// 1. Pojęcie herezji}

Zakres pojęcia herezji oraz sankcje stosowane wobec jednostek głoszących poglądy heretyckie zostały określone w Kodeksie Prawa Kanonicznego. Nadmienić należy, że w odniesieniu do odrzuconych dogmatów jednostka traci wiarę katolicką, zachowując jednocześnie wiarę chrześcijańską (Cito 2012: 35). W takim znaczeniu herezja pozostaje pojęciem „wewnętrznym”, regulującym status wyznawców jedynie Kościoła rzymskokatolickiego. Tym samym bezzasadne wydaje się określanie mianem „heretyka” osoby lub głoszonych przez nia poglądów „herezja”" w przypadku braku przynależności do tego Kościoła.

Cytując kanon 751 Kodeksu Prawa Kanonicznego (KPK 1983) za herezję uznać można ,uporczywe, po przyjęciu chrztu, zaprzeczanie jakiejś prawdzie, w którą należy wierzyć wiarą boską i katolicka, albo uporczywe powatpiewanie o niej”. Przedmiotem herezji sa prawdy objawione i autentycznie podane do wierzenia przez Magisterium Kościoła - w uroczystym orzeczeniu bądź powszechnym i zwyczajnym nauczaniu. Dokument Kongregacji Nauki Wiary (1998) wskazuje, że do uznania nauki za dogmatyczna nie jest potrzebna definicja, ale potwierdzenie, że prawda powinna być uznana za ostateczną z uwagi na podanie „,w sposób nieomylny przez Magisterium zwyczajne i powszechne jako oparta na słowie Bożym spisanym”. Poniżej dogmatów w nauczaniu Kościoła rzymskokatolickiego znajduje się nauczanie definitywne. W kategorii tej odrzucenie prawd nie jest herezja, ,ale sprawia, że odrzucający nie jest już w pełnej komunii z Kościołem katolickim" (Kongregacja Nauki Wiary 1998). Przykładami prawd definitywnych są: udzielanie święceń wyłącznie mężczyznom oraz doktryna o niegodziwości eutanazji. Z kolei kara ekskomuniki dotyczy jedynie osób, które dopuszczają się herezji formalnej, świadomie i dobrowolnie głosząc herezję. Kodeks nie przewiduje kary w przypadku „herezji” materialnej, czyli nieświadomego głoszenie poglądów sprzecznych z przyjętymi prawdami.

Analiza dyskursu nasuwa wniosek, że znaczenie nadawane pojęciu współcześnie odzwierciedla spór między postępem, nowoczesnością czy sekularyzmem, które w religii widzą ostatecznie pogrzebany relikt, nieprzystający do wartości globalizującego się świata - wolności i rozumu a ponowoczesnością, postsekularyzmem czy Baumanowską „retrotopia” (Bauman 2018), czyli swoista epidemia nostalgii za utracona przeszłością i obawa przed negatywnymi zmianami niesionymi przez przyszłość. Pierwsze oznaki tych zmian dostrzec można w widmach sekularyzacji Zachodu, a samą manifestację lęku przed degeneracyjnymi przemianami - w dys-

\section{/ 158 STANRZECZY 1[18]/2020}


kursie dotyczącym zmian obyczajowych. Michał Warchala zauważa, że postsekularyzm to nie tyle powrót wypartej przez nowoczesność religii, ile oparte na paradoksie połączenie odrzucenia religii w rozumieniu struktury zbudowanej na bazie ,zwartego systemu dogmatycznego skodyfikowanego w teologii" (Warchala 2014: 74) oraz włączenia pojęć i intuicji wypracowanych przez religię do nowej formy, będącej w kontrze wobec oświeceniowego redukcjonizmu. W takim ujęciu posługiwanie się herezja przestaje być przedmiotem walki z modernizmem i oznaką przegranego procesu postępu. Zamiast tego staje się narzędziem naprawy rzeczywistości, refleksji nad (nie)intencjonalnymi czy narzuconymi zmianami niesionymi przez nurt nowoczesności. Poruszając się w konfliktowym rozumieniu nowoczesności, Jürgen Habermas (2002) dostrzega w postsekularyzmie element wypośrodkowujący między agresywnym dualizmem: sekularyzmem a fundamentalizmem religijnym. Ilustrującym to podejście przykładem jest zmiana stosunku Kościoła rzymskokatolickiego do idei ekumenizmu. Przez lata ewoluował on od szafowania pojęciem herezji wobec innowierców, będącego emanacją fundamentalizmu, do wypracowania nauki, zgodnie z którą „prawdziwą herezją jest potępianie ekumenizmu” (Konferencja Episkopatu Polski 2017a), co uznać można za postsekularyzacyjną reinterpretację rzeczywistości w nowych warunkach, pozwalających na włączenie elementów wcześniej potępionych. Poszukując źródeł różnic w stanowisku wobec nowoczesności, wskazać można też na podejście Nowej Lewicy (por. Badiou 2007; Žižek 2008), w którym to nie religia per se poddana jest krytyce, ale jej sprzeciwiające się chrześcijańskim wartościom przejawy.

\section{/// 2. „Pozadogmatyczne” znaczenie herezji}

Rozważana w artykule debata wokół herezji i ortodoksji w kontekście kwestii dzielących Kościół wzdłuż osi moralnej zawiera się w soborowej $D e$ klaracji o wolności religijnej, w której stwierdza się: „władza cywilna winna troszczyć się o to, by nigdy, czy w sposób otwarty, czy ukryty, nie była naruszana $\mathrm{z}$ powodów związanych $\mathrm{z}$ religia równość obywateli $\mathrm{w}$ dziedzinie prawa, należąca przecież do wspólnego dobra społeczności, i żeby wśród obywateli nie miała miejsca dyskryminacja" (Sobór Watykański II 1966). Dyskusję nad kwestiami spornymi należałoby umieścić w jej kontekście z uwagi na to, że odnosi się ona do wszystkich uczestników życia społecznego. Zadaniem władzy cywilnej byłoby zapobieganie postawie dyskryminacji w stosunku do tych, którzy wyznają inne poglądy (Kłoczkowski 2011). W przypadku analizowanych „herezji”’: homoseksualnej i na- 
cjonalizmu, można także podjąć wątek gnostycyzmu, który doktrynerom daje pewną niedostępną innym wiedzę czy formę interpretacji Pisma, która zaprowadzić ma wyznawców do zbawienia. W ten sposób w herezji nacjonalizmu tworzony jest zarzut wobec modernizmu. Postuluje się zachowanie niezmiennej wiary w zmiennych okolicznościach, powołując się na zapisy Pisma Świętego. Brak możliwości wypełnienia tego postulatu wiąże się przede wszystkim z mającym już miejsce uczynieniem wiary bardziej przystępną (języki narodowe, powszechny dostęp do dokumentów), modyfikacja języka czy sposobów mówienia o samych prawdach wiary. Prymas Polski abp Wojciech Polak w kontekście herezji nacjonalizmu i sytuacji politycznej stwierdza, że „prawda jest jedna, fundamentalna i niezmienna, jednak musimy pogodzić się z faktem, że różne są drogi dochodzenia do niej” (Archidiecezja Gnieźnieńska 2018). W analizie dyskursu medialnego zwykło się postrzegać różnice w wykładni niektórych fragmentów Pisma w zależności od światopoglądu, moralności i przekonań politycznych.

Pewną formę odwrócenia herezji dostrzec można w czymś, co w dyskursie nazywa się „herezją ekologiczną” i która swój początek bierze z Synodu Amazońskiego w 2019 roku. Kościół naucza, że aby uznać nauczanie papieża za nieomylne, musi on ogłosić, że jest ono wiążącym głosem Magisterium, oraz stwierdzić, że katolicy muszą do nauczania podejść z wiara. Określony przez papieża Franciszka grzech ekologiczny oraz „poglądy stojące w sprzeczności z biblijnym przesłaniem «czyńcie sobie ziemię poddaną)" stały się zarzewiem konfliktu i powodem ostrzeżeń abpa Marka Jędraszewskiego o narzucanie siłą ideologii i kwestionowanie kultury (Gazeta Wyborcza 2019). W dyskursie opiniotwórczych mediów poglądy te przedstawione są w dość uproszczony sposób, jednak sądzić można, że tam, gdzie papież dostrzega troskę o klimat, zwolennicy tezy o „ekoherezji” postrzegaja wpływ obcej kultury (Bończa-Tomaszewski 1996), podważenie osobowości i wolności jednostki (Polonia Christiana 2019) czy zagrożenie panteizmem (Cieniek 2019) - elementy po części sprzeczne z nauczaniem definitywnym Kościoła, a więc niestanowiące bezpośrednio herezji². Wspólnoty wyznaniowe, najczęściej z kręgu protestanckiego, podchodzą do kwestii ochrony klimatu od innej strony, czego przykładem jest umieszczanie w kazaniach i agendzie kwestii działań na rzecz ochrony środowiska naturalnego.

Poniżej analizie poddaję dwie „herezje”, które uwidaczniają różne podejścia do postsekularyzmu. Kościół rzymskokatolicki w osobie hierar-

${ }^{2}$ Ks. prof. dr hab. Bogdan Ferdek (2008) dostrzega ponadto genezę „próby przybrania ekologii w szaty religii” w ruchu New Age, syntetyzującym głęboką ekologię, kult Gai i hipotezę Gai. 
chów (Episkopatu) oraz publicystów w analizowanych przypadkach (herezja nacjonalizmu versus herezja modernizmu oraz herezja homoseksualna) przybiera zarówno optykę otwartości, założenia personalizmu, według którego „człowiek jest osoba - wartością niepowtarzalną i nieprzemijajacą" (Wojtyła 1999: 97), jak i postawę zamkniętą, opartą na sprzeczności z ideami chrześcijaństwa. O ile pierwszy typ zakorzeniony jest w piśmiennictwie, o tyle drugi realizuje się głównie przez wypowiedzi medialne i homilie. W obu optykach użycie pojęcia herezji realizuje zgoła odmienne cele $-\mathrm{z}$ jednej strony staje się obroną tożsamości, legitymizacją istnienia grupy własnej przez odwołanie do obrony instytucji, która wydaje się tego zagrożenia nie dostrzegać. W drugim przypadku jest próbą zapobieżenia niekorzystnym zmianom na poziomie społecznym i oczyszczenia na poziomie instytucjonalnym.

\section{/// 2.1. Herezja nacjonalizmu versus herezja modernizmu}

Dwie postacie „rzekomego” odejścia od nauczania Kościoła w kwestiach życia narodowego zakorzenione są w poglądzie o podziale tegoż życia na dwie formy etyczno-społeczne: $z$ jednej strony nacjonalizm, $z$ drugiej kosmopolityzm, obie prowadzące do tworzenia błędnych zasad życia społecznego (Piwowarczyk 1957: 315). Badając dyskurs medialny dotyczący „herezji”, zauważyć można zaangażowanie dwóch aktorów: ruchów nacjonalistycznych (i duchownych sprzyjających ideologii nacjonalistycznej - katolicyzm zamknięty) oraz Episkopatu (wraz z publicystami katolickimi uznającymi wykładnię Kościoła - katolicyzm otwarty).

„Herezja nacjonalizmu” nazywana jest aktywność ruchów narodowych, niejako pod sztandarem Boga i obrony chrześcijaństwa, stanowiąca wewnętrzną sprzeczność (Deon 2018). Dokument Konferencji Episkopatu Polsku pt. Chrzésicianski kształt patriotyzmu (2017b) wskazuje dokładnie na postawy przeciwstawiające się patriotyzmowi: egoizm narodowy, nacjonalizm kultywujący poczucie wyższości narodu oraz zamykanie się na inne wspólnoty narodowe i wspólnotę ogólnoludzką. Zarówno w Magisterium Kościoła, jak i w dokumentach Episkopatu nacjonalizm nie został jednoznacznie potępiony bądź pochwalony. Stanowisko Kościoła wspiera obecny w encyklikach papieskich pluralizm. Papież Jan XXIII (1963), wychodząc od słów „narody maja wobec siebie wzajemne prawa i obowiązki”, stwierdza w encyklice Pacem in terris, że prawo moralne zapisane w naturze ludzkiej, kierujące zasadami współżycia poszczególnych jednostek, powinno rządzić wzajemnymi stosunkami pomiędzy narodami. W nauczaniu pa- 
pieża istotne znaczenie dla budowy tych stosunków mają zasady prawdy, solidarności, sprawiedliwości, wolności i miłości. Przy ich uznaniu wszystkie narody równe są co do godności oraz suwerenności. W nauczaniu Jana Pawła II wyraźnie rozgraniczone zostały pojęcia „patriotyzmu” i „szowinizmu" (1979: 16). Podczas gdy pierwszy wiązać można z bytem danym od Boga i w tym kontekście postrzegany jest pozytywnie, to fanatyczne i agresywne formy patriotyzmu pod postacia ,,szowinizmu” postrzegane sa przez papieża jako zarzewie nowych konfliktów (1995a: 27) oraz antytezę prawdziwego patriotyzmu (1995b), który wiąże się ze złączonym z Bogiem narodem. Zarówno w nauczaniu Jana Pawła II, jak i w dokumencie KEP znaleźć można opartą na pluralizmie i postawie katolicyzmu otwartego stanowczą krytykę prób ,podnoszenia własnego narodu do rangi absolutu, czy też szukania chrześcijańskiego uzasadnienia dla szerzenia narodowych konfliktów i waśni” (Konferencja Episkopatu Polski 2017b) oraz stwierdzenie, że należy odrzucić „,koncepcje i praktyki, [...] które traktują naród i państwo jako rzeczywistość samoistną i stawiaja je ponad wszelkimi innymi wartościami” (Jan Paweł II 1979a: 16). W liście apostolskim z okazji 50. rocznicy rozpoczęcia II wojny światowej (Apostolisches Schreiben zum 50. Jahrestag des Beginns des Zweiten Weltkriegs) Jan Paweł II (1989) dostrzega niebezpieczeństwo totalnej natury ideologii nacjonalistycznej oraz jej dążenie do stania się religia. Podobne stanowisko znajduje się w dokumencie końcowym Światowego Zgromadzenia na rzecz Sprawiedliwości, Pokoju i Integralności Stworzenia, wydanym przez kościoły zrzeszone w Polskiej Radzie Ekumenicznej. Kościoły deklarują w nim występowanie przeciwko rasizmowi, dyskryminacji i podziałom, a także odrzucają wypaczenie praw człowieka i narodów, wskazując na przymierze z Bogiem i bogatą różnorodność Bożego stworzenia (SIDE 1993: 54).

Problemem określenia nacjonalizmu i modernizmu jako herezji jest stworzenie jednoznacznej definicji oraz wskazanie jednostek, które wchodzą w zakres tak skonstruowanego pojęcia - stają się „wyznawcami” nacjonalizmu bądź modernizmu, wobec których stosować można sankcje. „Zespół herezyj”, jak Pius X definiuje modernizm katolicki w encyklice Pascendi dominici gregis (1907), ma na tyle płynnie określone granice postaw i przekonań godzących w nauczanie Kościoła, że aparat interpretacyjny zawarty w encyklice pozwala przyjmować, że „z jednej tezy z koniecznością wynikają wszelkie inne wnioski”. Powszechność użycia pojęcia do określenia pewnej zbiorowości stanowi nadinterpretację stworzona na potrzeby obrony czystości doktryny katolickiej. Jednocześnie nie jest konsekwencja wcześniejszego stosowania pojęcia, związanego głównie z integrystyczną

\section{/ 162 STANRZECZY 1[18]/2020}


publicystyką, wymierzoną w liberalizm w myśleniu. Modernizm w takim ujęciu stanowić ma zwarty system światopoglądowy, prowadzący „do calkowitego zniszczenia wiary i kultury katolickiej" (Rogalski 2018: 22-23). Za modernizmem stać maja pycha i ignorancja, prowadzące do przedkładania filozofii nowoczesnej nad nauczanie Kościoła. Tworzona przez encyklikę postawa zamknięcia i potępienia działalności intelektualnej na gruncie teologii katolickiej doprowadziła do interpretowania przez pryzmat dokumentu papieskiego także tego, co wykraczało poza jego kompetencje, prowadząc do podziału na katolików i heretyków (czy szerzej niekatolików; Piazzoni 2004) oraz rozszerzania „antymodernistycznego” nurtu na walkę z modernizmem społecznym i politycznym, przejawiające się w ponadwyznaniowym charakterze chadecji i próbach jej uniezależnienia od hierarchii kościelnej (Arnold 2009: 12).

Podczas gdy w znaczeniu religijnym klątwą obłożyć można jednostkę uporczywie zaprzeczająca prawdzie, a wykluczyć ze wspólnoty tych, którzy wyznają określone, niezgodne z nauczaniem poglądy, w przypadku analizowanych zjawisk dochodzi do sytuacji, w której definicja pozostaje płynna, a konflikt nierozwiązany. Sama interpretacja nauczania Kościoła, który postrzega naród jako wspólnotę szczególną, najbliżej związaną z rodzina i najważniejszą dla dziejów duchowych człowieka (Jan Paweł II 1979b), nie określa dokładnie, w którym momencie duma narodowa staje się szowinizmem czy raczej nie określa na tyle przekonująco i jednoznacznie, aby tworzyć wizję Kościoła, jakiego dana grupa pragnie doświadczać (Wałach 2018). To uwidacznia opozycję między katolicyzmem otwartym a jego wykluczająca wersją. Analiza dyskursu medialnego dotyczącego działania ruchu narodowego w kontekście potępianych przez Kościół praktyk (głównie nienawiść rasowa, tłumaczona ochroną tożsamości narodowej i katolickiej) ukazuje też brak spójności programowej i praktykę odcinania się od potępianych poglądów i zachowań, gdy te przekroczą pewną granicę. Obecne na Marszu Niepodległości w 2017 roku hasła rasistowskie doprowadziły do zapowiedzi rzecznika prasowego Stowarzyszenia „Marsz Niepodległości” (MN), dotyczącej podjęcia działań prewencyjnych w kolejnym roku (Do Rzeczy 2017a). Definicja narodowców w dyskursie publicznym jest szersza niż Ruch Narodowy (RN), w którego skład wchodzi kilkadziesiąt organizacji. Mimo że w założeniach RN potępiany jest separatyzm rasowy, Młodzież Wszechpolska (MW; wystąpiła z RN w 2015 roku) wpisuje go we własną tożsamość, odcinając się jedynie od nazizmu (Do Rzeczy 2017b) to z kolei doprowadziło do usunięcia ze strony konsolidującej środowiska patriotyczne artykułu jawnie popierającego separatyzm, a dalej wyrażenia 
sprzeciwu MW wobec działań zachowawczych (Busse 2017a). Wskutek odcinania się spójne określenie tożsamości „heretyków” staje się niemożliwe. Jednocześnie samodefinicja środowisk nacjonalistycznych zawiera ścisłe zakorzenienie w naukach katolickich, które manifestować się ma w hasłach „Bóg, Honor, Ojczyzna” oraz „Wielka Polska Katolicka” (Liwski 2016). Działania analizowanej grupy, mające być odzwierciedleniem Wiary, swoje uzasadnienie odnajdują w nauczaniu Piusa XI oraz kardynała Stefana Wyszyńskiego (który podobnie jak Jan Paweł II odróżniał patriotyzm od jego „wypaczonej formy” oraz z którego inicjatywy powstał List o chræeśijańskim patriotyzmie; Konferencja Episkopatu Polski 1975). Ruch Narodowy posługuje się w swojej retoryce wprost fundamentalizmem religijnym, zarówno w deklaracjach, jak i w definicji wroga, określanego mianem „herezji katolickiego modernizmu” (Busse 2017b). Dookreślenie pojęcia w dyskursie medialnym zawiera w sobie wiele wątków: od laicyzacji i „letniości” wiernych (Radio Maryja 2019), przez odejście od nauki Kościoła na rzecz ideologii lewicowej (również wśród kleru): marksizmu, „deprawującej w szkołach ideologii LGBT" i zwalczania rodziny, aż po samą krytykę piętnowania nacjonalizmu przez Kościól. Jedynym źródłem odnowy moralnej narodu i społeczeństwa w ujęciu Ruchu Narodowego ma być odwołanie do wartości katolickich (Ruch Narodowy 2018), jednak nie w wersji inkluzywnej, a wykluczającej pewne grupy. Swego rodzaju paradoks stanowi obrona tradycji (rozumianej jako „czystość”) w ramach samego Ruchu, w którym zaproszenie Bawera Aondo-Akaa, działacza narodowego, zostało skomentowane „Naród jest [...] grupa ekskluzywną i nie można sobie do niej ot, tak wejść $[. .$.$] nie wygadujmy jednak bzdur, [...], że takie osoby sa Polaka-$ mi” (Bartkiewicz 2017). W podobnej kontrze do katolickiego pluralizmu stoi hasło „śmierć wrogom ojczyzny” (Siewniak 2018) oraz odejście od powszechności (otwartości) Kościoła na rzecz jego narodowo-katolickiej wersji (Sobańda 2018). Uzasadnieniem dla takiego braku tolerancji może być interpretacja tezy o braku pluralizmu prawdy (Kołakowski 2019), która w badanym przypadku ewoluuje w skrajną ksenofobię. Znajduje to również swój wyraz w rozróżnieniu na „,nurt polskości rdzennej, etnicznej i nurt polskości kulturowej” (Przeciszewski 2019) i tym samym wyraźnym określeniu osi sporu poprzez potępienie pierwszej przez KEP (2018).

Wskazana wcześniej płynność definicji tego, co wchodzi w skład herezji katolickiego modernizmu (w nauczaniu Kościoła), pozwala narodowcom na swobodne konstruowanie wrogich elementów, z którymi należy podjąć walkę w obronie tradycji. To, co nazwać można dziedzictwem katolicyzmu ostatnich lat - zbudowanie wizji religii, w której polskość, katolickość 
i otwartość stanowi o tożsamości i sile jednoczącej Kościół - przez nacjonalistów postrzegane jest jako siła niszcząca go od środka, ulegająca obcym ideologiom (por. Ruch Narodowy 2018). W odpowiedzi na te zarzuty KEP wskazuje na dorobek Polski w tworzeniu modelu patriotyzmu otwartego, gościnnego, „włączającego, inspirującego się dorobkiem sąsiadów i całej chrześcijańskiej europejskiej kultury”, dzięki któremu „Polakami stawali się ci, którzy Polakami zostać chcieli, bez względu na swoje pochodzenie" (2017b). W liście KEP odnaleźć można zaczerpnięta z nauczania papieża wizję patriotyzmu, w której „(p)rawdziwy patriota, miłujący swój naród, nie ulega agresji i instynktom nakazującym wykluczanie i stygmatyzowanie społeczne innych osób, różniących się światopoglądem, wiara, pochodzeniem etnicznym czy odcieniem skóry".

Poszukując źródeł herezji w znaczeniu dogmatycznym w działaniu zarówno grup narodowych, jak i ich przeciwników należałoby wskazać na dwa odstępstwa. Pierwszym z nich jest obowiązujący katolików aktywny sprzeciw wobec form herezji w zakresie dogmatu o życiu uświęconym oraz legalizacji prawnej związków między osobami tej samej płci (Kongregacja Nauki Wiary 2003). W tej interpretacji sprzeciw wobec „herezji katolickiego modernizmu", mającej wyraz w liberalizacji, wydawać się może zgodny z dokumentem Kongregacji Nauki Wiary, zaniechaniem zaś byłoby milczenie. Drugim odstępstwem, bardziej w sensie metaforycznym, jest manicheistyczne odwoływanie się do walki dobra (Ruch Narodowy, pragnący odrodzenia moralnego kraju i społeczeństwa) z siłami zła (obce ideologie, marksizm, zepsucie moralne). U podstawy analizowanego określania działań mianem herezji wydaje się leżeć jednak proces poszukiwania, umacniania czy walki o tożsamość. Podczas gdy Episkopat zajmuje jasne stanowisko w kwestii ochrony życia i dogmatów, zobowiązany jest do głoszenia Ewangelii miłosierdzia i pokoju. Tożsamość nacjonalistów konstytuuje się przez wykluczanie ze wspólnoty tych, którzy w jakiś sposób się w niej wyróżniają. Nie może się to realizować inaczej niż poprzez Barberowski „dżihad”, skierowany przeciwko obcym „plemionom”, które obwinia o własne niepowodzenia (Kołakowski 1974), i krytykę tych, którzy wyłamują się z definicji Prawdy na rzecz koncyliacyjnej ugodowości, o która chociaż oskarża się papieża Franciszka, to widoczna jest (w analizowanym kontekście tożsamości narodowej) również w naukach jego poprzedników. W celu obrony tworzony jest Kościół Walczący, który „bezkompromisową postawą w obronie Wiary w sferze publicznej" sprzeciwia się formom wypaczeń, ujętych jednak według własnej wykładni Pisma (Busse 2017b). Wskazanie efemerycznego wroga, katolickiego modernizmu, z którym wal- 
czyć może dana grupa, spaja międzygrupowe więzi i koncentruje uwagę na zwalczaniu Obcego. Działanie w obronie Kościoła pozwala legitymizować istnienie grupy wśród jednostek i instytucji o poglądach prawicowych, z drugiej strony zaś daje dostęp do zasobów związanych z wiarą (świątynie, duszpasterstwo).

\section{/// 2.2. Herezja homoseksualna}

W przeciwieństwie do płynnie określonej herezji nacjonalizmu, herezja homoseksualna posiada rozbudowany aparat pojęciowy. Z analizy wyłaniaja się dwa zjawiska, zdające się mieć odmienne cele. „Homoherezja” łączona jest $\mathrm{w}$ dyskursie medialnym $\mathrm{z}$ jednej strony ze zmianami w porządku prawnym, z drugiej - z wpływem ponowoczesności w myśleniu jednostek i próbą modyfikacji znaczenia słów: „rodzina”, „małżeństwo”, „płeć”. Konserwatywne media katolickie ten typ „herezji” postrzegaja m.in. poprzez systematyczną działalność „lobby homoseksualnego” w przestrzeni publicznej i Kościele, szkodzącą strukturze kleru (Kowalczyk 2016). Krytyce poddane jest także „prowadzące do rozłamu” postsekularyzacyjne podejście kościołów protestanckich do kapłaństwa kobiet, udzielania ślubów osobom tej samej płci i duszpasterstwa osób otwarcie manifestujacych orientację nieheteronormatywną, czyli swoiste tworzenie „pomostu” między sekularyzacją i fundamentalizmem religijnym. Pozwala to z jednej strony budować przekonanie, że w polskim Kościele kwestia ta jest marginalna (zob. Terlikowski 2004), z drugiej wzbudzać zaniepokojenie możliwościa przybrania przez zjawisko skali widocznej na Zachodzie (Kratiuk 2013), tym samym już na tym etapie legitymizować działania zapobiegające rozprzestrzenianiu się problemu i dokładnie definiować wroga. Określanie przemian społeczno-politycznych mianem herezji przyjmuje formę „retrotopii” (Bauman 2018), w której kluczową wartością jest obrona polskiego Kościoła przed narzucona z zewnątrz niszcząca zmianą obyczajowa. Realizuje się to m.in. poprzez nakreślanie niekorzystnych procesów społecznych (skutki rewolucji z 1968 roku, tj. zmiana podejścia do etyki seksualnej, pornografii i ochrony życia) oraz porównywanie postawy Kościołów w krajach zlaicyzowanych (brak stanowczej reakcji) z działaniem polskiego Kościoła (Lisicki, Wybranowski 2019).

W wydanej w 1975 roku przez Kongregację Nauki Wiary (wówczas Święta Kongregację Nauki Wiary) deklaracji Persona bumana (1975) powtórzony został pogląd o grzesznym charakterze stosunków nieobjętych sakramentem małżeństwa, ze szczególnym wskazaniem na stosunki ho-

\section{/ 166 STANRZECZY 1[18]/2020}


moseksualne: „(w) Piśmie Świętym są one potępione jako poważna deprawacja, a nawet sa przedstawione jako zgubne następstwo odrzucenia Boga" (por. Listy Apostolskie św. Pawła). Także w późniejszych dokumentach w większym stopniu przedmiotem wykładni Kościoła są stosunki płciowe czy realizacja skłonności „do postępowania złego z moralnego punktu widzenia” (Kongregacja Nauki Wiary 1986), a nie sama skłonność. Z powodu wiążącego się z orientacją homoseksualną ,moralnego nieuporządkowania”, dokument z 1992 roku, wskazując na zrównanie dyskryminacji osób homoseksualnych z dyskryminacją rasową, zaznacza, że nie ma ona miejsca w przypadku, ,gdy chodzi o adopcję dziecka lub powierzenie go opiekunom, zatrudnienie nauczycieli lub trenerów sportowych, służbę wojskowa”" (Kongregacja Nauki Wiary 1992), a prawa moga zostać „słusznie ograniczone” ze względu na „obiektywnie nieuporządkowane zachowania" (w kontekście dokumentu: chorobę fizyczną lub umysłowa). W nauczaniu Kościoła sprzeciwienie się modernizmowi wydaje się, podobnie jak w przypadku herezji nacjonalizmu, próbą obrony ważnych dla wspólnoty wartości, przy zachowaniu jednak ewangelicznego szacunku i solidarności z bliźnim ${ }^{3}$ oraz wykluczeniu tych grup, które sprzeciwiaja się interpretacji Prawdy ${ }^{4}$. Nauczanie Kościoła podnosi zatem kwestię skutków homoseksualizmu, a nie samego zjawiska - usankcjonowania prawnego małżeństw między osobami tej samej płci (Jan Paweł II 1994) czy zagrożenia dla istnienia rodziny poprzez uczynienie związków homoseksualnych modelem dla współczesnego społeczeństwa (Kongregacja Nauki Wiary 2003). Tę część dyskusji nad „herezja” charakteryzuje połączenie tradycyjnej interpretacji rzeczywistości, niewykluczającej jednostek, ale wskazującej pożądane postawy i niepożądane zachowania wyłączające ze wspólnoty5.

W dyskursie przejawem herezji jest wskazane już dopuszczanie osób o orientacji homoseksualnej do święceń kapłańskich i biskupich, co doprowadzić ma do zmiany „logiki sakramentalnej”, związanej z pełnieniem posługi i sprawowaniem sakramentów przez duchownych (Kowalczyk 2016). Magisterium Kościoła katolickiego uznaje za swoją oficjalną część Instrukcje... papieża Benedykta XVI dotyczącą rozeznawania powołania u osób o skłonnościach homoseksualnych (Kongregacja Edukacji Katolickiej 2005), według której do seminarium nie powinny być przyjmowane osoby

\footnotetext{
${ }^{3}$ W dyskursie jednostka określana jest jako zagubiona, wymagająca integracji (por. Deutsche Welle 2013).

${ }^{4}$ Nie ma tutaj wskazania na jednostkę, zakłada się bowiem, że może ona „nawrócić się”, „zintegrować”, w przeciwieństwie do „ideologii”, określanych jako złe / nakłaniające do czynienia zła.

${ }^{5}$ Wobec osób o orientacji homoseksualnej Katechizm Kościoła Katolickiego zaleca unikać oznak niesłusznej dyskryminacji (KKK 1992: 2358).
} 
o głęboko zakorzenionych tendencjach homoseksualnych oraz wspierajace „kulturę gejowską”, rozumianą przez promowanie „zaburzonych i nietrwałych więzi międzyludzkich oraz tworzenie par egoistycznych, które nie inwestuja swych sił i środków finansowych we własne dzieci" (Dziewiecki 2005). Spójna z tym definicja „herezji homoseksualnej”, widoczna już nie w nauczaniu, ale w dyskursie medialnym, zwłaszcza w wypowiedziach środowisk prawicowych, mówi o narażeniu dzieci na czyny pedofilne ze strony duchownych wykazujących skłonności homoseksualne oraz istnieniu „homo-mafii” (MWł 2018; „mafii homoseksualnej” - Chołodowski 2019), której działania przejawiają się poprzez duszpasterstwo wśród osób identyfikujących się z ruchem LGBT i brak reakcji papieża posiadającego wiedzę o przypadkach pedofilii klerykalnej. Zarzuty te łączą się z tym, co środowiska narodowe określają mianem herezji modernizmu, a zatem uleganiem lewicowym „wpływom”. Łączenie homoseksualizmu duchownych z pedofilią klerykalną (Wiejak 2019) staje się jedną z kwestii, która spaja poglądy środowisk prawicowych odnośnie do źródeł współczesnych problemów Kościoła (Lawnicki 2018) - stawianie wyżej dobra ofiar pedofilii w rzeczywistości legitymizuje jednak walkę z herezją i zjawiskiem, któremu przypisuje się źródło pedofilii klerykalnej. Zdefiniowanie „herezji homoseksualnej”, wraz z wypowiedziami duchownych ${ }^{6}$ pozwala poprzez odwołanie do tradycji dokonać translacji aktualnych problemów. Oskarżenia pod adresem „homolobby”, podszyte homofobią i nienawiścią, także ze strony homoseksualistów (Bartoś 2013), wyodrębniają iterację modernizmu - za homoseksualizmem podążają wskazane wcześniej problemy, jak pedofilia duchownych. Podczas gdy w zewnętrznej warstwie działania wydają się wcieleniem wersji katolicyzmu zamkniętego, wykluczającego, opartego na zaprzeczaniu idei miłosierdzia i solidarności, Kościół tworzy „retrotopię”, w której wykluczanie, piętnowanie i wskazywanie „heretyków" pozwala na zatrzymanie zmian, widocznych poza polskim Kościołem, a zarazem rozwiązanie przypisywanych mu problemów przez wskazanie ich zewnętrznego źródła (wPolityce 2018).

Tak jak Magisterium Kościoła nie uznaje homoseksualizmu per se jako herezji (brak dogmatu), podobnie w naukach społecznych nie istnieje „,ideologia homoseksualna" (ideologia LGBT), mająca być tworzona w celu promowania zachowań homoseksualnych i „,werbowania osób heterosek-

\footnotetext{
${ }^{6}$ Najbardziej charakterystyczne wydają się być wypowiedzi abpa Marka Jędraszewskiego o „tęczowej zarazie" (Lisicki, Wybranowski 2019), obarczanie homoseksualizmu winą za większość problemów dotyczących pedofilii przez abpa Stanisława Gądeckiego (wPolityce 2018) i wypowiedzi duchownych o istnieniu „homolobby” (Bartoś 2013; Gospodarek 2019).
}

\section{/ 168 STANRZECZY 1[18]/2020}


sualnych do homoseksualnego stylu życia”. Podejście takie stało się już przedmiotem krytyki: z jednej strony przez obalenie mitu „homoseksualnego werbunku" poprzez działania nakierowane na walkę z dyskryminacja oraz o prawa obywatelskie (Harris 2009: 8), z drugiej - walkę z utożsamianiem go z pedofilia (tamże: 156; Fejes 2008: 30).

Potrzebę tworzenia pojęcia „herezji homoseksualnej” interpretować można z kolei za Michelem Foucaultem jako formę biowładzy, mająca przywrócić homoseksualnych przedstawicieli kleru społeczeństwu poprzez potępienie zachowań niezgodnych z przyjętymi przez instytucję zasadami. Religia pozostaje jedną z dziedzin produkujących bogaty dyskurs wokół seksualności, określając interpretacje, zasady i jednostki, które moga się w nim wypowiadać. Wymaga przy tym bezwzględnego posłuszeństwa ze strony wyznawców, używając ,jednostkowego imperatywu zmuszajacego każdego człowieka do poddawania własnej seksualności ustawicznemu dyskursowi, aż po wielorakie mechanizmy, które [...] zachęcają, wyodrębniaja, porządkują, instytucjonalizują mówienie o seksie" (Foucault 2000a: 36). Z uwagi na dążenie jednostek (wiernych) do zbawienia władza ma prawo zobowiązać je do wszystkiego, co do zbawienia prowadzi, kierując się przede wszystkim dobrem jednostki, a nie jej wolnością. Nie może ona jednak osiagnąć zbawienia sama, niezbędna jest rola przewodnika i akceptacja jego autorytetu (Foucault 2000b: 210-211), co legitymizuje wykluczanie, nadając mu znaczenie wyższej konieczności. Wykluczający język prawicowej debaty publicznej (m.in. wypowiedź abpa Jędraszewskiego o zarazie, którą należy właściwie zdiagnozować i leczyć) obraca się w nurcie powstrzymywania zmian związanych $\mathrm{z}$ rewolucją kulturowa (do tych samych argumentów odnosi się Benedykt XVI, poszukując źródeł pedofilii klerykalnej; Stasik 2016) i ,ateizacyjnego walca światopoglądu marksistowskiego" (Lisicki, Wybranowski 2019).

\section{/// Wnioski}

Dyskusja nad analizowanymi zjawiskami odbywa się zarówno w dyskursie medialnym, jak i kościelnym, jednak pojęcie herezji w badanych przypadkach odchodzi od stricte teologicznego wskazywania naruszeń nauczania Magisterium przez heretyków. Zamiast tego staje się przedmiotem symbolicznej władzy, umożliwiając sprawowanie „sądów” nad odstępcami od określonej wizji Kościoła. Wyłaniający się z analizy dyskursu podział na ,wiernych” i „niewiernych” wyznaczony jest nie poprzez zagadnienia dogmatyczne, ale podejście do kwestii moralnych, wobec których istnieje 
jedynie nauczanie definitywne Kościoła. To z kolei nie pozwala na formułowanie zarzutów o głoszenie herezji. Użycie w analizowanych przypadkach pojęcia służy raczej wskazaniu i uprawomocnianiu kształtu Kościoła - utrzymania status quo, przyjęcia postawy wynikającej z postsekularyzmu czy tworzenia „retrotopii”, broniącej instytucji przed niepożądanymi zmianami. Walka $z$ herezją katolickiego modernizmu w pierwszym przypadku legitymizuje cel istnienia grupy i jej tożsamość, narażając jednak obrońców na miano heretyków przez dopuszczanie się odstępstw od nauczania Kościoła. W drugim przypadku, poprzez definiowanie modernizmu przez lewicowe „ideologie”, pojęcie herezji pozwala zarówno na uchronienie się przed podzwonnym, jak i sprawowanie symbolicznej władzy poprzez wskazanie konkretnego, zewnętrznego wroga, odpowiedzialnego za dziejące się szkodliwe procesy toczące instytucję. Tym samym pozwala na wykorzystanie zarzutów wobec Kościoła do umocnienia jego dyskursywnej i politycznej pozycji, co obserwować można zwłaszcza w dyskursie politycznym dotyczącym praw mniejszości.

Bibliografia:

Literatura przedmiotu

/// Arnold C. 2009. Mała historia modernizmu, tłum. T. Zatorski, Wydawnictwo WAM.

/// Badiou A. 2007. Świety Paweł. Ustanowienie uniwersaližmu, tłum. J. Kutyła, P. Mościcki, Ha!art.

/// Barber B.R. 2004. Dízihad kontra McŚwiat, tłum. H. Jankowska, Muza.

/// Bauman Z. 2018. Retrotopia. Jak rzadzi nami przeszłość?, tłum. K. Lebek, Wydawnictwo Naukowe PWN.

/// Berger P. 1999. The Desecularization of the World. A Global Overview, [w:] tegoż, The Desecularization of the World. Resurgent Religion and World Politics, William B. Eerdmans Publishing.

/// Cito D. 2012. Delicta graviora contro la fede e sacramenti, [w:] Questioni attuali di diritto penale canonico, Libreria editrice vaticana.

/// Fejes F. 2008. Gay Rights and Moral Panic. The Origins of America's Debate on Homosexuality, Palgrave Macmillan. 
/// Foucault M. 2000a. Historia seksualności, t. I: Wola wiedzy, tłum. B. Banasiak, T. Komendant, K. Matuszewski, Czytelnik.

/// Foucault M. 2000b. Seksualność i władza, [w:] tegoż, Filozofia, historia, polityka. Wybór pism, tłum. D. Leszczyński, L. Rasiński, Wydawnictwo Naukowe PWN, s. 201-218.

/// Habermas J. 2002. Wierzyć i wiedzié, tłum. M. Lukasiewicz, „Znak”, nr 7, s. 8-21.

/// Harris W.C. 2009. Queer Externalities. Hazardous Encounters in American Culture, SUNY Press.

/// Hindes B. 1999. Filozofie władzy. Od Hobbesa do Foucaulta, tłum. D. Leszczyński, L. Rasiński, Wydawnictwo Naukowe PWN.

/// Jan Paweł II. 1979a. Encyklika „Redemptor hominis”, https://opoka.org. pl/biblioteka/W/WP/jan_pawel_ii/encykliki/r_hominis.html; dostęp: 5.02.2020.

/// Jan Paweł II. 1979b. Homilia w crasie Mszy świetej odprawionej na placu Zwyciestwa, 02.06.1979 roku, http://nauczaniejp2.pl/dokumenty/wyswietl/ id/538; dostęp: 4.03.2021.

/// Jan Paweł II. 1989. Apostolisches Schreiben zum 50. Jahrestag des Beginns des Zweiten Weltkriegs, http://www.vatican.va/content/john-paul-ii/de/ apost_letters/1989/documents/hf_jp-ii_apl_19890827_anniv-beginning-ii-world-war.html; dostęp: 5.02.2020.

/// Jan Paweł II. 1994. Modlitwa Anioł Pański z 20.02.1994, „L’Osservatore Romano", nr 4, s. 39.

/// Jan Paweł II. 1995a. List apostolski Tertio millennio adveniente, Pallottinum, https://opoka.org.pl/biblioteka/W/WP/jan_pawel_ii/listy/tertio.html; dostęp: 5.02.2020.

/// Jan Paweł II. 1995b. Præemówienie Jego Światobliwości Papieża Jana Pawta II aygtoszone na forum 50. sesji Zgromadzenia Ogólnego ONZ (Nowy Jork, 5 października 1995 r.), „Studia i Materiały / Polski Instytut Spraw Międzynarodowych", nr 100, s. 14.

/// Jan XXIII. 1963. Encyklika o pokoju miedzy wszystkimi narodami opartym na prawdzie, sprawiedliwości, mitości i wolności „Pacem in terris”, Wrocławska Księgarnia Archidiecezjalna. 
/// KKK. 1992. Katechiz̨m Kościoła Katolickiego, Pallottinum.

/// Kołakowski L. 1974. Moje stusæne poglady na wszystko, Znak.

/// Kołakowski L. 2019. Chrześcijaństwo, Znak.

/// KPK. 1983. Kodeks Prawa Kanonicænego, red. P. Majer, Wolters Kluwer.

/// Piazzoni A.M. 2004. Historia wyboru papieży, tłum. M. Lehnert, Wydawnictwo $\mathrm{M}$.

/// Pius X. 1907. Pascendi dominici gregis, http://sanctus.pl/index.php?grupa=89\&podgrupa=500\&doc=450; dostęp: 10.08.2020.

/// Piwowarczyk J. 1957. Katolicka etyka spoteczna, Veritas.

/// Rogalski M. 2018. Producenci margaryny? Marian Zdziechowski i polski modernizm katolicki, Universitas.

/// Sobór Watykański II. 1966. Deklaracja o wolności religijnej „Dignitatis bumanae”, „Acta Apostolicae Sedis”, nr 58, s. 929-946.

/// Terlikowski T.P. 2004. Teczowe chrześcijaństwo: homoseksualna berezja w natarciu, QLCO.

/// van Dijk T.A. 1993. Elite Discourse and Racism, Sage Publications.

/// Warchala M. 2014. Romantyzm i narodżiny myśli postsekularnej, „Logos i Ethos", nr 36, s. 73-85.

/// Wojtyła K. 1999. Rozważania o istocie çłowieka, Wydawnictwo WAM.

/// Žižek S. 2008. O wieræe, tłum. B. Baran, Aletheia.

\section{Literatura podmiotu}

/// Archidiecezja Gnieźnieńska. 2018. Prymas o nacjonalizmie $i$ wojnie polsko-polskiej, http://www.archidiecezja.pl/aktualnosci/archiwum/2018/ maj/prymas_o_nacjonalizmie_i_wojnie_polskopolskiej.html; dostęp: 5.02.2020.

/// Bartkiewicz A. 2017. Bawer Aondo-Akaa. Nienygodny narodowiec, https:// www.rp.pl/Plus-Minus/311169900-Bawer-Aondo-A kaa-Niewygod nynarodowiec.html; dostęp: 5.02.2020. 
/// Bartoś T. 2013. Homolobby, https://natemat.pl/blogi/tadeuszbartos/65057,homolobby; dostęp: 10.08.2020.

/// Bończa-Tomaszewski N. 1996. Gteboka ekologia, czyli stara herezja w nowych eko-szatach, https://www.fronda.pl/a/gleboka-ekologia-czyli-staraherezja-w-nowych-eko-szatach,101275.html; dostęp: 5.02.2020.

/// Busse A. 2017a. BUSSE: Separatyzm rasowy - odpowiedźn na multikulti w XXI wieku. 16 SIERPNIA 2017, http://tenetetraditiones.blogspot.com/2017/11/ busse-separatyzm-rasowy-odpowiedz-na.html; dostęp: 10.08.2020.

/// Busse A. 2017b. Nacjonalizm a Kościót Katolicki, https://medianarodowe. com/nacjonalizm-a-kosciol-katolicki/; dostęp: 5.02.2020.

/// Chołodowski M. 2019. „Mafia bomoseksualna w Kościele winna pedofili讠”. Marsz dla Życia i Rodziny w Biatymstoku, https://bialystok.wyborcza.pl/bialystok/7,35241,24802806,mafia-homoseksualna-w-kosciele-winna-pedofilii-marsz-dla.html; dostęp: 10.08.2020.

/// Cieniek R. 2019. Synod dla Amazonii. Ewolucja Kościoła w cieniu skandali [ANALIZA], https://wiadomosci.onet.pl/religia/aktualnosci/synod-oamazonii-historyczne-zmiany-nowy-grzech-i-zwyciestwo-franciszka/ tns8tqb; dostęp: 9.08.2020.

/// Deon. 2018. Czy katolicki nacjonalista to heretyke? Abp Jedraszewski odpowiada wiernym, https://deon.pl/kosciol/czy-katolicki-nacjonalista-to-heretykabp-jedraszewski-odpowiada-wiernym,496815; dostęp: 10.08.2020.

/// Deutsche Welle. 2013. „Nie mnie osadzać gejów”. Stowa papieża o homoseksualizmie, https://www.dw.com/pl/nie-mnie-os $\% \mathrm{C} 4 \% 85 \mathrm{dza} \% \mathrm{C} 4 \% 87-$ ge$\mathrm{j} \% \mathrm{C} 3 \% \mathrm{~B} 3 \mathrm{w}-\mathrm{s} \% \mathrm{C} 5 \% 82$ owa-papie $\% \mathrm{C} 5 \% \mathrm{BCa}$-o-homoseksuali $\% \mathrm{C} 5 \% \mathrm{BA}-$ mie/a-16987153; dostęp: 10.08.2020.

/// Do Rzeczy. 2017a. Rasistowskie hasła 11 listopada. Rzecznik. Marszu Niepodlegtości: Odcinamy sie od tego, https://dorzeczy.pl/kraj/46969/rasistowskie-hasla-11-listopada-rzecznik-marszu-niepodleglosci-odcinamy-sie-od-tego. html; dostęp: 4.03.2021.

/// Do Rzeczy. 2017b. Rz̧ecznik Mtodzৃė̇y Wszechpolskiej: Nie jesteśmy rasistami, ale separatystami rasowymi, https://dorzeczy.pl/kraj/46991/RzecznikMlodziezy-Wszechpolskiej-Nie-jestesmy-rasistami-ale-separatystami-raso wymi.html; dostęp: 4.03.2021. 
/// Dziewiecki M. 2005. List księzy-bomoseksualistów to promocja ,kultury” gejowskiej, https://opoka.org.pl/biblioteka/Z/ZD/odp_promog.html; dostęp: 5.02.2020.

/// Ferdek B. 2008. Ekoreligia, http://www.lexcredendi.pl/ekoreligia/; dostęp: 10.08.2020.

/// Gospodarek D. 2019. Ks. prof. Andrzej Kobylinski: O relacji homoseksualizmи z kaplanstwem, https://www.fronda.pl/a/ks-prof-andrzej-kobylinski-orelacji-homoseksualizmu-z-kaplanstwem,131878.html; dostęp: 10.08.2020.

/// Gazeta Wyborcza. 2019. Abp Jedraszenski w TV Republika pytany o Grete Thunberg $i$,ekologizm” cytuje Biblie: "Czyńcie sobie qiemie poddana”, https:// krakow.wyborcza.pl/krakow/7,44425,25545152,abp-marek-jedraszewski-w-telewizji-republika-ekologizm-to.html; dostęp: 5.02.2020.

/// Kłoczkowski J.A. 2011. Jak być heretykiem?, „Gazeta Wyborcza”, 22.01.2011.

/// Konferencja Episkopatu Polski. 1975. List Episkopatu Polski o chrzéścijańskim patriotyzmie, [w:] Listy pasterskie Episkopatu Polski 1945-1974, Éditions du Dialogue, s. 708.

/// Konferencja Episkopatu Polski. 2017a. Trwa Tydzień Modlitw o Jedność Chrześsijan, https://episkopat.pl/en/rozpoczal-sie-tydzien-modlitw-ojednosc-chrzescijan; dostęp: 5.02.2020.

/// Konferencja Episkopatu Polski. 2017b. Chrześcijanski ksztattpatriotyżmu. Dokument Konferencji Episkopatu Polski przygotowany przez Rade ds. Spotecznych, https://episkopat.pl/en/chrzescijanski-ksztalt-patriotyzmu-dokumentkonferencji-episkopatu-polski-przygotowany-przez-rade-ds-spolecznych/; dostęp: 5.02.2020.

/// Konferencja Episkopatu Polski. 2018. Być pielgrzymem pokoju, https:// episkopat.pl/slowo-rady-kep-ds-pielgrzymek-o-pielgrzymowaniunarodowym/; dostęp: 4.03.2021.

/// Kongregacja Edukacji Katolickiej. 2005. Instrukcja Kongregacji Edukacji Katolickiej nt. kryteriów rozeznawania powołania u osób z tendencjami bomoseksualnymi ubiegajacych sie o przyjecie do seminarium i dopuszcrenie do swieceń, https:// opoka.org.pl/biblioteka/W/WR/kongregacje/kedukacji/instrukcja_homos_04112005.html; dostęp: 5.02.2020. 
/// Kongregacja Nauki Wiary. 1975. Deklaracja o niektórych zagadnieniach etyki seksualnej „Persona bumana”, https://opoka.org.pl/biblioteka/W/WR/kongregacje/kdwiary/zbior/t_1_27.html; dostęp: 5.02.2020.

/// Kongregacja Nauki Wiary. 1976. Deklaracja o kwestii dopuszrzenia kobiet do kaplaństwa urzedowego, http://www.vatican.va/roman_curia/congregations/cfaith/documents/rc_con_cfaith_doc_19761015_inter-insigniores_ pl.html; dostęp: 5.02.2020.

/// Kongregacja Nauki Wiary. 1986. List do biskupón kościoła katolickiego o duszpasterstwie osób homoselesualnych „Homosexualitatis problema”, https://opoka.org.pl/biblioteka/W/WR/kongregacje/kdwiary/zbior/t_2_18.html; dostęp: 5.02.2020.

/// Kongregacja Nauki Wiary. 1992. Uwagi dotyczqce odpowiedzi na propozycje ustaw o niedyskryminacji osób homoseksualnych, http://www.vatican.va/roman_ curia/congregations/cfaith/documents/rc_con_cfaith_doc_19920724_ homosexual-persons_pl.html; dostęp: 5.02.2020.

/// Kongregacja Nauki Wiary. 1998. Wyjaśnienie doktrynalne dotyczace końcowej czéśi formuly ,Wyznania wiary”, https://opoka.org.pl/biblioteka/W/WR/ kongregacje/kdwiary/wyzn_wiary.html; dostęp: 5.02.2020.

/// Kongregacja Nauki Wiary. 2003. Uwagi dotyczqce projektón legalizacji zwiazkón między osobami homoseksualnymi, https://opoka.org.pl/biblioteka/W/ WR/kongregacje/kdwiary/homo_03062003.html; dostęp: 12.03.2021.

/// Kowalczyk D. 2016. Homoseksualna herez ja, „Idziemy”, nr 5(539), s. 9.

/// Kratiuk K. 2013. Księża ₹ Wenus, https://www.pch24.pl/ksieza-z-wenus,19025,i.html; dostęp: 5.02.2020.

/// Lisicki P., Wybranowski W. 2019. Walec rewolucji można zatrzymać w Polsce, https://dorzeczy.pl/kraj/123519/walec-rewolucji-mozna-zatrzymac-w-polsce.html; dostęp: 10.08.2020.

/// Liwski M. 2016. Mateus₹ Liwski: Nasz cel to Wielka Polska Katolicka, https://www.nacjonalista.pl/2016/10/29/mateusz-liwski-nasz-cel-towielka-polska-katolicka/; dostęp: 10.08.2020.

/// Lawnicki T. 2018. Gtos Terlikowskiego - gtosem rozsadku. Katolicki publicysta o ksieżach-pedofilach, https://natemat.pl/257053,tomasz-terlikowski-opedofilii-w-kosciele-wsrod-ksiezy-specjalna-komisja; dostęp: 4.03.2021. 
/// MW. 2018. Abp Marek Jedraszewski: „Teczowa zaraza, jak epidemia cholery”, https://krakow.wyborcza.pl/krakow/7,44425,25517337,abp-marek-jedraszewski-teczowa-zaraza-jak-epidemia-cholery.html; dostęp: 10.08.2020.

/// MW1. 2018. Skandal homoherezji. Raport PCb24, https://www.pch24.pl/ skandal-homoherezji--raport-pch24,62417,i.html; dostęp: 5.02.2020.

/// Polonia Christiana. 2019. Herezje na synodzie? Hierarchowie waywaja do krucjaty modlitwy $i$ postu, https://www.pch24.pl/herezje-na-synodzie-hierarchowie-wzywaja-do-krucjaty-modlitwy-i-postu,70801,i.html; dostęp: 10.08.2020.

/// Przeciszewski M. 2019. Kościót wobec patriotyzmu i nacjonalizmu, https:// www.gosc.pl/doc/6047766.Kosciol-wobec-patriotyzmu-i-nacjonalizmu/8; dostęp: 5.02.2020.

/// Radio Maryja. 2019. X Marsz Niepodlegtości przeszedt ulicami Warszawy, https://www.radiomaryja.pl/informacje/x-marsz-niepodleglosciprzeszedl-ulicami-warszawy/; dostęp: 5.02.2020.

/// Ruch Narodowy. 2018. Suwerenny naród w XXI wieku. Program Ruchu Narodowego, https://ruchnarodowy.net/wp-content/uploads/Program-Ruchu-Narodowego.pdf; dostęp: 10.08.2020.

/// SIDE. 1993. Światowe Zgromadzenie na rzecz Sprawiedliwości, Pokoju i Integralności Stworzenia, Seul, Republika Korei, 5-12 marca 1990. Dokument końcowy, „Studia i Dokumenty Ekumeniczne”, nr 1(31), s. 49-71.

/// Siewniak R. 2018. Duch fatszywej religii na Marszu Niepodległości, https:// deon.pl/kosciol/komentarze/duch-falszywej-religii-na-marszu-niepodleglosci,458822; dostęp: 5.02.2020.

/// Sobańda A. 2018. Prof. Jacek Leociak: Polski Kościót w swoim rdzeniu jest herezja, ponieważ w wiekszości jest narodowo-katolicki, https://kultura.dziennik. pl/ksiazki/artykuly/574182,prof-jacek-leociak-polski-kosciol-w-swoimrdzeniu-jest-herezja-poniewaz-w-wiekszosci-jest-narodowo-katolicki.html; dostęp: 5.02.2020.

/// Stasik E. 2016. Benedykt XVI skarży się na „,brud” w Kościele katolickim, https://www.dw.com/pl/benedykt-xvi-skar\%CC5\%BCy-si\%C4\%99-nabrud-w-ko\%C5\%9Bciele-katolickim/a-19536360; dostęp: 10.08.2020. 
/// Wałach M. 2018. Narodowcy chca Boga! Kto im Go pokaże?, https://www. pch24.pl/narodowcy-chca-boga--kto-im-go-pokaze-,59622, i.html; dostęp: 8.08.2020.

/// Wiejak A. 2019. Nachalna herezja chorej ideologii. Czy prymaska Szwecji, aby na pewno wie, co czyni?, https://wpolityce.pl/kosciol/469853-nachalna-herezja-chorej-ideologii; dostęp: 5.02.2020.

/// wPolityce. 2018. Abp Stanisław Gadecki mówi wprost: Więeszosíc problemów dotyczacych pedofilii wiaże sie z homoseksualizmem, https://wpolityce.pl/kosciol/ 426734-zwiazek-pedofilii-i-homoseksualizmu-abp-gadecki-mowi-wprost; dostęp: 10.08.2020.

\section{/// Abstrakt}

W dyskursie medialnym wielokrotnie zauważyć można posługiwanie się pojęciem herezji, odbiegającym od znaczenia uzgodnionego w debacie naukowej i teologicznej. W określaniu danego zjawiska tym mianem w mniejszym stopniu chodzi o obecne zwłaszcza w dialogu ekumenicznym napięcia i odstępstwa od nauki Kościoła rzymskokatolickiego. Współczesne herezje zdają się w większym stopniu opierać na odstępstwach od powszechnych interpretacji nauk Kościoła lub wręcz przeciwnie - dążą do przywrócenia tradycjonalizmu nauk. W artykule zbadano dwie współczesne osie konfliktu, określane przez uczestników debaty jako „herezje”. Wykorzystując metodę krytycznej analizy dyskursu oraz analizę danych zastanych, poszukiwano odpowiedzi dotyczącej genezy takiego ujęcia zagadnienia, powodów jego uważniania (kontrsepizacji) oraz zaangażowanych w proces aktorów, a także jawnych i ukrytych celów badanych fenomenów. W analizowanych przypadkach posługiwanie się pojęciem „herezji” służy realizacji interesów elit symbolicznych oraz jest skutecznym narzędziem legitymizowania tożsamości grupowej.

Słowa kluczowe:

herezja, analiza dyskursu, homoseksualizm, nacjonalizm, modernizm 


\section{/// Abstract}

\section{The Concept of Heresy as an Instrument of Power in the Media Discourse}

In the media discourse, the concept of heresy is often given a meaning which deviates from the meaning agreed upon in the scientific and theological debate. Defining a specific phenomenon as a "heresy" is less about deviation from the teaching of the Roman Catholic Church and more about departures from common interpretations of those teachings or about seeking to restore their traditionalism. This article examines two contemporary axes of conflict that are called heresies by the participants in the debate. Using the methods of critical discourse analysis and analysis of the available data, answers were sought regarding the genesis of the heresies, the reasons for their being recognised as such, and the actors in the process, as well as the explicit and hidden goals of the phenomena. In the cases analysed, the use of the concept of "heresy" served the interest of symbolic elites and was an effective tool for legitimising group identity.

Keywords:

heresy, discourse analysis, homosexuality, nationalism, modernism

/// Monika Strupiechowska - doktorantka na Wydziale Socjologii Uniwersytetu Warszawskiego. Zajmuje się badaniem polskiego dyskursu publicznego oraz działania grup interesu w kontekście tworzenia polityk publicznych. W ostatnim czasie opublikowała artykuły dotyczące polskich panik moralnych, które ukazały się m.in. w „Prakseologii”, „Mediach i Społeczeństwie” oraz „Społeczeństwie i Polityce”.

ORCID: https://orcid.org/0000-0002-0732-1152

E-mail:m.strupiechowska@gmail.com 